TranscUlturAl, vol. 12.1 (2020), 118.

http://ejournals.library.ualberta.ca/index.php/TC

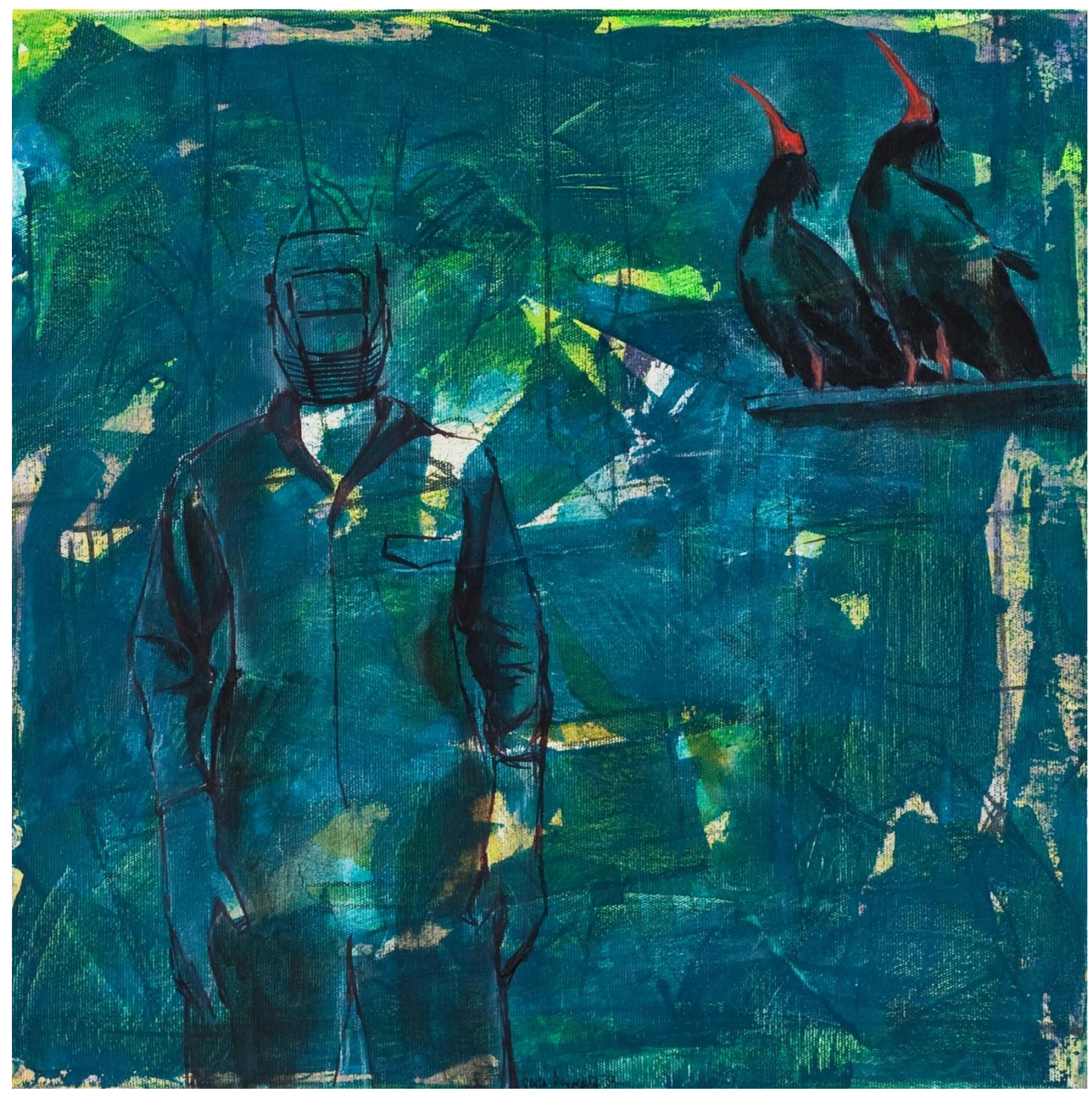

\title{
With the Bald Ibis
}

2009

Mixed media on canvas $40 \times 40 \mathrm{~cm}$

(C) Beyza Boynudelik 